\title{
RANCANG BANGUN MODUL PELATIHAN DENGAN MENGGUNAKAN SENSOR, SISTEM KENDALI DAN AKTUATOR ELEKTRONIK
}

\author{
Elka Faizal ${ }^{1}$, Indrawan Nugrahanto ${ }^{2}$, Sungkono ${ }^{3}$ \\ 1,2,3Program Studi Teknik Mesin Produksi dan Perawatan \\ Jurusan Teknik Mesin - Politeknik Negeri Malang \\ Jl. Soekarno Hatta No.9 Kota Malang, Jawa Timur \\ E-mail : elka.faizal@polinema.ac.id, indrawan.nugrahanto@polinema.ac.id, sungkono@polinema.ac.id
}

Receive: 23 Desember 2020

Accepted: 23 Januari 2021

\begin{abstract}
ABSTRAK
Penggunaan perangkat otomasi berupa sensor, sistem kendali, maupun aktuator berasal dari berbagai jenis, model, merk, dan tipe sudah lazim digunakan pada berbagai kegiatan di dunia industri. Pengetahuan pengguna sangat dperlukan untuk menggunakan perangkat industri yang berbeda-beda ini sebagai upaya kesalahan saat penggunaannya. Namun, masih banyak ditemukan mahasiswa dan masyarakat umum yang belum memahami cara penggunaan perangkat-perangkat yang lazim digunakan di dunia industri. Hal ini yang mendasari penulis untuk membuat sebuah modul pelatihan yang dapat digunakan sebagai media pembelajaran yang akan memberikan pengetahuan mengenai piranti yang lazim digunakan di industri seperti sensor proximity, temperature controller, dan relay. Modul pelatihan yang dirancang penulis ini digunakan sebagai media praktikum mahasiswa pada mata kuliah Sensor dan Transducer dengan harapan mahasiswa mampu memahami penggunaan sensor, kendali dan actuator elektronik sebagai persiapan mahasiswa menghadapi dunia industri.

Kata Kunci: Modul pelatihan Sensor proximity Kendali suhu
\end{abstract}

\section{PENDAHULUAN}

Pada dewasa ini, pertumbuhan ekonomi melaju dengan pesat sebagai akibat industrialisasi. Perkembangan ekonomi tersebut seringkali berbanding terbalik dengan kapasitas ketersediaan tenaga kerja manusia yang ada maupun atas alasan efisiensi biaya. Karena itu, untuk menunjang kebutuhan perkembangan industri secara global, banyak perusahaan-perusahaan multinasional yang melakukan pengembangan teknologi di dalam bidang penginderaan (sensor), kendali (controller), dan penggerak (actuator) berbasis elektronik, untuk memenuhi sebagian kebutuhan industri atas tenaga kerja dan efisiensi.

Hadirnya teknologi baru ini, memerlukan pengembangan kapasitas sumber daya manusia untuk implementasi, mendukung secara teknis dan operasinya. Pengembangan kapasitas manusia ini dilakukan dengan cara melakukan pelatihan-pelatihan penggunaan teknologi tersebut. Pelatihan teknologi dalam bidang sensor, kendali, dan penggerak dapat dilakukan untuk mencapai hasil pembelajaran (learning outcome) dalam beberapa tingkat, antara lain: pemahaman, aplikasi, analisis, atau evaluasi. Pada tingkat kemampuan aplikasi, diharapkan peserta pelatihan setelah mengikuti pelatihan, dapat menerapkan 
JT : Jurnal Teknik

P-ISSN: 2302-8734

E-ISSN: 2581-0006
Vol. 10 No. 1 Th. 2021

Halaman : $17-23$ Januari 2021

pengetahuannya untuk menentukan, memodifikasi, mengoperasikan, serta memecahkan masalah yang berhubungan dengan jenis-jenis sensor, controller, dan actuator yang biasa digunakan pada lingkungan industri.

Namun, kendala yang sering muncul dalam pelatihan penggunaan teknologi tersebut adalah terbatasnya sarana praktikum, sehingga banyak pelatihan/pembelajaran mengenai teknologi tersebut hanya melibatkan simulasi menggunakan komputer, tanpa mengenal secara fisik dari komponen yang akan digunakan tersebut. Hal ini menyebabkan kurang dalamnya pemahaman peserta pelatihan yang berimbas pada kemampuan menerapkannya. Oleh sebab itu, untuk mencapai hasil pelatihan berupa kemampuan aplikasi, maka diperlukan metode pelatihan berupa praktikum dengan dilengkapi modul pelatihan yang umum digunakan di dunia industri sehingga peserta didik memiliki pemahaman yang lebih baik serta kemampuan menerapkan yang baik pula. Maka untuk menyikapi hal tersebut dilakukanlah "Rancang Bangun Modul Pelatihan dengan Penggunaan Sensor, Kendali dan Aktuator Elektronik" yang harapannya dapat meningkatkan pemahaman dan penerapan pada peserta didik terhadap apa yang disampaikan.

\section{METODE PENELITIAN}

\section{KAJIAN LITERATUR DAN PENGEMBANGAN HIPOTESIS}

- Catu Daya

Pada alat ini catu daya berfungsi sebagai penghasil tegangan masukan dari sumber energi untuk memasuk daya ke beban.

- Sensor

Pada alat ini sensor berfungsi sebagai pendeteksi perubahan besaran baik fisik maupun kimiawi. Variabel keluaran dari sensor yang dirubah menjadi listrik disebut transduser.

- Controller

Pada alat ini controller berfungsi sebagai pengendali sistem.

- Aktuator

Aktuator merupakan bagian yang berfungsi melakukan gerakan berdasarkan perintah dari bagian kendali. Gerakan yang dilakukan dapat berupa gerakan translasi, maupun gerakan rotasi.

- Piranti Pelindung Rangkaian Elektrik 
JT : Jurnal Teknik

P-ISSN: 2302-8734

E-ISSN: 2581-0006
Vol. 10 No. 1 Th. 2021

Halaman : $17-23$

Januari 2021

Pada rangkaian listrik, piranti perlindungan umumnya digunakan untuk mencegah overcurrent akibat hubungan singkat pada rangkaian.

METODE PERHITUNGAN

Arus nominal adalah arus kerja dari suatu peralatan listrik.

In $=I_{\text {base }}=\frac{\text { Sbase }}{\sqrt{3} \mathrm{v}_{\text {base }}}$

Dengan :

$I_{n}=I_{\text {base }}=$ Arus nominal A)

$S_{\text {base }}=$ Daya semu (VA)

$V_{\text {base }}=$ Tegangan (V)

Metode Perhitungan Output Tegangan

Vout $=$ Vin $x(R 1 /(R 1+R 2))$

Rumus Daya

$$
\begin{aligned}
& \mathrm{P}=\mathrm{V} \text { I } \\
& \mathrm{P}=\operatorname{dava}(\mathrm{W}) \\
& \mathrm{V}=\operatorname{Voltase}(\mathrm{V}) \\
& \mathrm{I}=\operatorname{Arus}(\mathrm{A})
\end{aligned}
$$

Metode Perhitungan Hall - Effect Proximity Sensor

$$
\mathrm{V}_{\mathrm{H}}=\frac{K I B}{D}
$$

Dimana :

$\mathrm{V}_{\mathrm{H}}=$ Tegangan efek hall

$\mathrm{K}=$ Konstanta (bergantung pada material)

I = Arus dari sumber eksternal

$\mathrm{B}=$ Medan magnet

$\mathrm{D}=$ Konstanta ketebalan

\section{TEKNIK PENGAMBILAN DATA}

Prosedur dimulai dengan mengambil spesifikasi utama yang diperlukan berdasarkan fungsi komponen dari datasheet dengan membandingkan apa yang diukur dalam proses pengujian. Apabila terjadi masalah, maka dilakukan penggantian dengan komponen lain lalu dilakukan pengujian ulang untuk memastikan dapat bekerja dengan baik. vercurrent akibat hubungan singkat pada rangkaian (MCB).

Metodologi Pengujian 


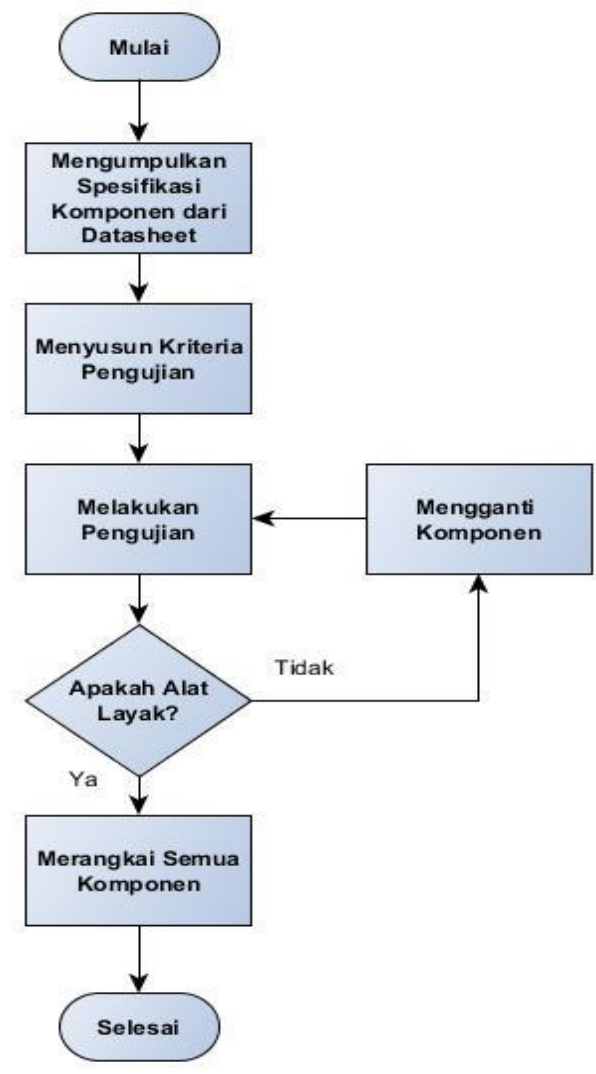

Gambar 1 Flowchart metodologi penelitian

\section{HASIL DAN PEMBAHASAN}

Pengujian Short Circuit MCB

MCB yang disingkat Magnetic Circuit Bracker berfungsi sebagai pengaman rangkaian dari arus pendek dengan cara memutus aliran listrik dari sumber menuju rangkaian. MCB yang digunakan pada alat memiliki arus 6A. Pengujian dilakukan sebanyak 20 kali dengan hasil MCB dapat berfungsi dengan baik.

Pengujian Power Supply DC 24V

Bertujuan untuk menguji fungsi sebagai penyedia tegangan DC 24 Volt. Pengujian dilakukan sebanyak lima (5) kali untuk masing-masing tingkat beban yaitu 0 watt, 5 watt, dan 10 watt dengan syarat tegangan keluaran tidak lebih rendah dari 23 volt. Adapun hasilnya komponen dapat berfungsi dengan baik. 
JT : Jurnal Teknik

P-ISSN: 2302-8734

E-ISSN: 2581-0006

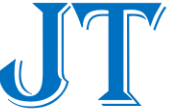

FT UMT
Vol. 10 No. 1 Th. 2021

Halaman : $17-23$

Januari 2021

Tabel 1 Hasil Uji Pilot Light Dengan Masukan AC 220V dan DC 24 Volt

\begin{tabular}{|c|c|c|c|c|c|c|}
\hline \multirow{2}{*}{ Masukan Tegangan } & \multicolumn{5}{|c|}{ Pengujian ke- } & \multirow{2}{*}{ Luaran yang dicapai } \\
\hline & 1 & 2 & 3 & 4 & 5 & \\
\hline AC 220 Volt & $\mathrm{v}$ & $\mathrm{v}$ & $\mathrm{v}$ & $\mathrm{v}$ & $\mathrm{v}$ & Berfungsi \\
\hline DC 24 Volt & v & $\mathrm{v}$ & $\mathrm{v}$ & $\mathrm{v}$ & $\mathrm{v}$ & Berfungsi \\
\hline
\end{tabular}

Tabel 2. Hasil Uji Sensor Induktif

\begin{tabular}{|c|c|c|c|c|c|c|}
\hline \multirow{2}{*}{ Benda Yang Dideteksi } & \multicolumn{5}{|c|}{ Pengujian ke } & \multirow{2}{*}{ Luaran yang dicapai } \\
\hline & 1 & 2 & 3 & 4 & 5 & \\
\hline Tidak ada benda & $\mathrm{x}$ & $\mathrm{x}$ & $\mathrm{x}$ & $\mathrm{x}$ & $\mathrm{x}$ & Tidak ada \\
\hline Benda Logam & $\mathrm{V}$ & $\mathrm{V}$ & $\mathrm{V}$ & $\mathrm{V}$ & $\mathrm{V}$ & Ada \\
\hline Benda non logal & $\mathrm{x}$ & $\mathrm{X}$ & $\mathrm{x}$ & $\mathrm{x}$ & $\mathrm{X}$ & Tidak ada \\
\hline
\end{tabular}

Tabel 3 Hasil Pengujian Alat

\begin{tabular}{|c|c|c|c|c|c|c|c|c|c|}
\hline Mode & $\begin{array}{l}\text { Set } \\
\text { Value }\end{array}$ & $\begin{array}{l}\text { Present } \\
\text { Value }\end{array}$ & $\begin{array}{l}\text { Status } \\
\text { Pemanas }\end{array}$ & $\begin{array}{l}\text { Status } \\
\text { Pendingin }\end{array}$ & Mode & $\begin{array}{c}\text { Set } \\
\text { Value }\end{array}$ & $\begin{array}{c}\text { Present } \\
\text { Value }\end{array}$ & $\begin{array}{c}\text { Status } \\
\text { Pemanas }\end{array}$ & $\begin{array}{c}\text { Status } \\
\text { Pendingin }\end{array}$ \\
\hline Pendingin & 30 & 30 & Mati & Aktif & Pemanas & 30 & 27 & Aktif & Mati \\
\hline Pendingin & 30 & 31 & Mati & Aktif & Pemanas & 30 & 29 & Aktif & Mati \\
\hline Pendingin & 30 & 32 & Aktif & Mati & Pemanas & 30 & 30 & Mati & Aktif \\
\hline Pendingin & 30 & 31 & Aktif & Mati & Pemanas & 30 & 29 & Mati & Aktif \\
\hline Pendingin & 30 & 30 & Mati & Aktif & Pemanas & 30 & 28 & Aktif & Mati \\
\hline
\end{tabular}

Dari hasil pengujian, dapat disimpulkan alat telah bekerja sesuai dengan hasil rancangan.

Untuk tambahan variasi, ditambahkan penempatan sensor proximity, baik dalam bentuk induktif maupun kapasitif. Selain itu, aktuator ditambahkan (Motor Stepper).

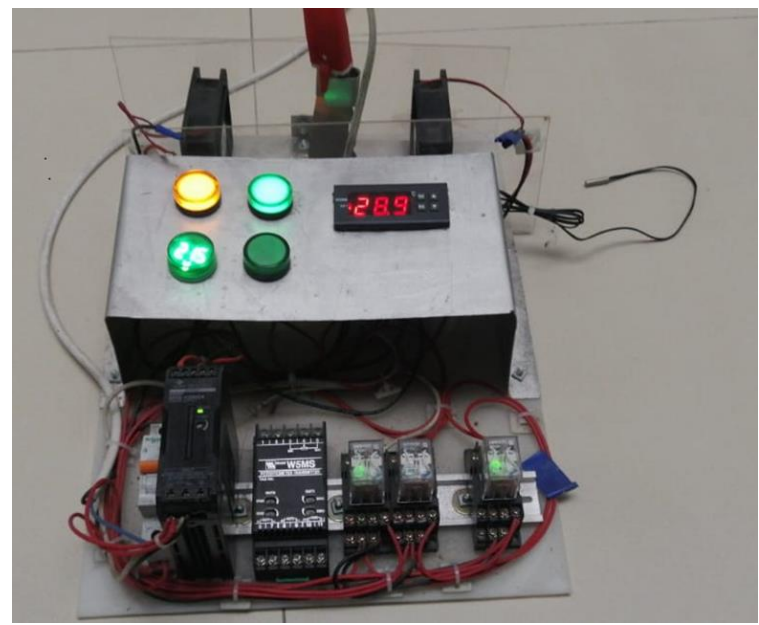

Gambar 2 Alat Peraga Modul Pelatihan dengan Penggunaan Sensor, Kendali dan Aktuator Elektronik 
JT : Jurnal Teknik

P-ISSN: 2302-8734

E-ISSN: 2581-0006
Vol. 10 No. 1 Th. 2021

Halaman : $17-23$ Januari 2021

\section{KESIMPULAN}

Berdasarkan kegiatan yang telah dilakukan, dapat ditarik kesimpulan sebagai berikut:

1. Piranti sensor yang digunakan adalah sensor induktif, kapasitif, dan suhu. Kontrolernya yaitu kontroler temperatur. Sementara Aktuatornya yaitu fan untuk menyimulasikan pendinginan, serta sebuah motor stepper.

2. Rancang bangun telah dirancang dalam bentuk diagram rangkaian, yang mana akan dapat digunakan sebagai panduan peserta untuk merangkai.

3. Pengujian yang telah dilakukan membuktikan bahwa alat telah berfungsi sebagaimana yang direncanakan.

\section{DAFTAR PUSTAKA}

Cooper W.D,. "Electronic Instrumentation and Measurement Techniques", New Delhi:PHI Gopel.W. Hesse, 1978.

E. Jasfi, "Metode Pengukuran Teknik (Terjemah dalam Bahasa Indonesia)",Jakarta : PT.Erlangga.

Ika Putri, "Panduan Praktikum Sensor dan Tranducer", Politeknik Negeri Malang: Dana DIPA, 2011.

J and Zemel J.N. ( ed )(1989). Sensors : A Comprehensive Survey, Vol I Weinheim : VCH Holman J.P (1985)

Jacob M.J.,"Industrial Control Electronics:Applications and Design", Englewood Cliffs:Prentice Hall International,Inc, 1989.

Kantrowitz.dkk, “Electronic Measurements", Englewood Cliffs, NJ: Prentice Hall Inc, 1979.

Kretschmar, M., \& Welsby, S., Capacitice and Inductive Displacement Sensors, in Sensor Technology Handbook. Burlington: Newnes,2005.

Moermond,J., "Sensor Choices for Pneumatic Cylinder Positioning", Diambil dari https://www.hydraulicspneumatics.com/technologies/cylindersactuators/article/21885196/sensor-choices-for-pneumatic-cylinder-positioning, 2016. Rangan.dkk, "Instrumentation Devices and Systems", New Delhi : Tata- McGraw Hill Publsh.Co.Ltd, 1990.

Simamora, R. H., "Buku Ajar Pendidikan”. Jakarta: EGC, 2009.

Sugiyono, “Metode Penelitian Kualitatif, Kuantitatif, dan R\&D”, Bandung: CV Alfabeta, 2007. 
JT : Jurnal Teknik

P-ISSN: 2302-8734

E-ISSN: 2581-0006
Vol. 10 No. 1 Th. 2021

Halaman : $17-23$

Januari 2021

William D. Cooper, "Instrumentasi Elektronik dan Teknik Pengukuran”, Edisi ke-2, Penerbit Erlangga, 1991. 